\title{
Lugares sagrados no oeste de Santa Catarina: marcas materiais da religiosidade popular nos municípios de Xanxerê, Bom Jesus, Ipuaçu e Entre Rios
}

Sacred places in Santa Catarina's west: material brands of popular religiousity in Xanxerê, Bom Jesus, Ipuaçu and Entre Rios

Tiago João Benetti*

Jaisson Teixeira Lino ${ }^{\star *}$

Fábio Araújo ${ }^{* *}$

Palavras-chave:

Lugares sagrados

Monges Santos

Movimento do Contestado

Keywords:

Sacred places.

Monks Saints

Contestado Movement
Resumo: O presente artigo apresenta o resultado de trabalhos de campo de identificação de sítios históricos em Xanxerê, Bom Jesus, Ipuaçu e Entre Rios no Estado de Santa Catarina associados à passagem de "monges santos" entre meados do século XIX e início do século XX. Foram registrados sete lugares classificados como grutas, capelas ou fontes d’água, denotando na atualidade a contínua utilização desses espaços para a realização de visitas e rituais, a se julgar pelos objetos e outros vestígios observados nesses locais. Os lugares associados às passagens dos "monges santos", em especial com São João Maria, são importantes marcadores físicos e simbólicos na paisagem regional, com grande potencial para estudos nas mais diversas áreas das ciências humanas.

\begin{abstract}
This article presents the results of fieldwork for the historical sites identification in Xanxerê, Bom Jesus, Ipuaçu and Entre Rios in Santa Catarina's State, associated with the "holy monks" passage between the middle of 19th century and the beginning of 20th century. Seven places were classified as caves, chapels or water sources, denoting the continuous use of these places for visits and rituals, judging by the objects and other vestiges observed in there. The places associated to "holy monks" passages, especially with St. João Maria, are important physical and symbolic markers in the regional landscape, with great potential for studies in the most diverse areas of the human sciences.
\end{abstract}

Recebido em 29 de maio de 2019. Aprovado em 30 de agosto de 2019.

\section{Considerações iniciais}

O presente artigo apresenta os resultados de levantamento de campo de lugares relacionados com aspectos do sagrado, em consonância com a história dos monges eremitas que circularam pela região de estudo de meados do século XIX até a eclosão da Guerra do Contestado, em 1912.

O recorte geográfico é a circunscrição geopolítica dos municípios de Xanxerê, Bom Jesus, Ipuaçu e Entre Rios, localizados na região oeste do Estado de Santa Catarina. O recorte temporal, entretanto, é aberto, pois se tornou difícil, para não dizer impossível, datar com precisão a constituição dessas formações naturais em espaços sagrados associados aos monges santos.

Do conjunto de lugares identificados pela população em geral como "lugares do monge" no oeste de Santa Catarina, registramos e descrevemos setes exemplares, entre grutas e fontes d’água. Esses espaços estão conectados com a história de sujeitos tidos como monges eremitas, que desde a metade do século XIX percorriam uma vasta região do sudeste e sul do Brasil dando conforto espiritual,

\footnotetext{
* Mestre em História pela Universidade Federal da Fronteira Sul (UFFS), Campus Chapecó/SC. E-mail: <tjbenetti@hotmail.com>.

** Doutor em Arqueologia pela Universidade de Trás-os-Montes e Alto-Douro (UTAD) de Portugal. Docente do Programa de Pós-Graduação em História na Universidade Federal da Fronteira Sul (UFFS), Campus Chapecó/SC. E-mail: <lino@uffs.edu.br>.

${ }^{* * *}$ Mestre em História pela Universidade Federal da Fronteira Sul (UFFS), Campus Chapecó/SC. E-mail: <fabio.ecohi@gmail.com>.
} 
procedendo a batismos/benzeduras e receitando ervas com caráter de cura. A história registrou três desses monges tornados santos pela população: João Maria Agostini, João Maria de Jesus e José Maria de Jesus (CABRAL, 1960).

Eloy Tonon (2008), em sua tese de doutorado - oportunidade em que se dedicou ao estudo desses personagens históricos recorrentemente convocados pela memória quando o tema em pauta é o Contestado - ajuda-nos a entender um pouco sobre a escolha dos monges por grutas e fontes d'água como abrigos. Para além dos locais tomados por abrigos, Tonon $(2008$, p. 95$)$ indica-nos outros aspectos característicos desses personagens quando afirma que:

Os monges do Contestado adotaram práticas de vida dos remanescentes medievais, não em toda sua plenitude, mas parcialmente, desapegados dos bens terrenos, contemplativos, celibatários, mortificando o corpo com uma alimentação frugal, gozavam de uma reputação de santidade, advinda de suas rezas predições e curas, austeridade na vestimenta, alimentação e forma de albergar-se. Vestiam-se modestamente, alimentavam-se de donativos, dormiam ao relento, sempre próximos a olhos de água ou ainda em grutas, não aceitavam pouso em casas de seguidores. A prática da disciplina física foi, a exemplo dos monges medievais, um fator de estímulo para uma diversidade de visões e predições difundidas.

Ainda de acordo com Tonon (2008), a atuação dos monges do Contestado pode ser compreendida por duas categorias: a espiritual e a curativa; ambas responsáveis por reunir seguidores que não se dispersavam após as rezas e os procedimentos de cura realizados, e permaneciam próximos aos locais de pouso dos monges. Esses locais de pouso, grutas e fontes d’água - como já dito, eram objetos de veneração entre os crentes nos monges, e as águas e restos de cinzas eram coletados por esses crentes por serem considerados elementos "sagrados" e "milagrosos".

Considerando o caráter espiritual desses eremitas, alguns lugares a eles associados foram sendo também, por assim dizer, espiritualizados.
Assim, grutas que serviram de abrigo temporário, fontes d'água que podem ter sido batizadas $\mathrm{e}$ cruzeiros que podem ter sido erigidos pelos monges foram recebendo um caráter sagrado com o passar do tempo.

Os referidos espaços foram tornando-se locais privilegiados para a realização de rituais religiosos, de caráter católico popular ${ }^{1}$, juntamente com a materialização por meio da deposição de imagens, ex-votos e demais objetos de culto. Também, com o passar do tempo, esses lugares foram sendo antropizados, por meio de alterações como a instalação de aparatos hidráulicos para uma melhor coleta das águas de fontes "santas", para citar um exemplo.

A respeito da manutenção e sacralização de determinados espaços considerados sagrados, Segundo Karsburg (2014, p. 1038):

Os locais de devoção constituem-se em lugares de memória e de identidade. $\mathrm{Na}$ tentativa de bloquear o esquecimento e de fixar a experiência, águas santas, grutas e altares são oferecidos ao monge, configurando-se como verdadeiro Patrimônio Cultural das populações.

A memória coletiva e a interação com artefatos e locais que remetem a lembranças, transmitem sentimentos de vida e consagração de determinados fatores que aproximam o presente e o passado; então, segundo Nora (1993, p. 8): "Se habitássemos ainda nossa memória, não teríamos necessidade de consagrar lugares de memória”.

A memória é inerente ao convívio social, e apresenta concepções identitárias, principalmente quando envolve locais coletivos de lembranças. E, conforme salienta Nora (1993, p. 9):

A memória é a vida, sempre carregada por grupos vivos e, neste sentido, ela está sempre em evolução, aberta a dialética da lembrança e do esquecimento, inconsciente de sua deformações sucessivas, vulnerável a todos os usos e manipulações, susceptível de longas latências e repetitivas revitalizações.

Tais representações e concepções de memórias coletivas podem ser observadas no 
que relata Karsburg (2014, p. 1038), a respeito da manutenção de espaços sacralizados e crenças transmitidas coletivamente:

O Patrimônio Imaterial é transmitido de geração em geração e constantemente recriado pelas comunidades e grupos em função de seu ambiente, de sua interação com a natureza e de sua história, gerando um sentimento de identidade e continuidade, contribuindo, assim, para promover $\mathrm{o}$ respeito à diversidade cultural e à criatividade humana.

A manutenção de memória e de espaços sacralizados caminha lado a lado quando observamos as ações promovidas pelos adeptos à crença do Monge do Contestado, não separando a religiosidade e determinados costumes ancestrais de atividades contemporâneas de demonstração de fé.

Para além da contribuição como mapeamento, na segunda parte do artigo realizamos algumas reflexões ligando os lugares registrados com alguns prolegômenos interpretativos em um campo que aqui denominamos de "arqueologia do sagrado".

\section{Registro de lugares dos monges}

Metodologicamente, pautamos nossa pesquisa de campo em métodos arqueológicos clássicos de deteç̧ão de sítios arqueológicos, provenientes, sobretudo, de pesquisas sob a rubrica da arqueologia preventiva, utilizada em projetos de licenciamento de empreendimentos potencialmente causadores de impactos no solo e, consequentemente, de destruição de vestígios arqueológicos e históricos.
Desse modo, realizamos entrevistas informais com moradores da região indagando-os sobre os lugares dos monges, haja vista o amplo conhecimento que os habitantes de Xanxerê e região têm sobre esses espaços. Mediante a metodologia de levantamento oportunístico e após a localização do sítio, procedemos ao preenchimento de ficha padrão para o registro de sítios arqueológicos que foi sugerida pelo Instituto do Patrimônio Histórico e Artístico Nacional (IPHAN), com a anotação de aspectos formais de cada espaço, cujas sínteses são descritas a seguir.

\section{Fonte e capitel Cerro Doce}

Fonte d'água localizada dentro da Reserva Indígena Xapecó, na localidade conhecida como Cerro Doce, a cerca de $10 \mathrm{~km}$ do centro da cidade de Ipuaçu/SC. O local é de difícil acesso, e parte do percurso é feito a pé. Além da vertente, encontramos uma capela (ou capitel, como é conhecido), com diversas imagens de santos católicos e uma pequena imagem do Monge e, na base da imagem, está escrita a palavra "Profeta". Nesse local são realizados cultos e algumas pessoas "benzem" os enfermos, costumam fazer chás e remédios para diversas moléstias e afirmam que a água dessa fonte tem propriedades medicinais. Dentro de uma capela com cerca de $7 \mathrm{~m}^{2}$, encontram-se diversas imagens de santos católicos, assim como panelas, crucifixos, adereços coloridos (enfeites de Natal, papéis de presente), flores de plástico e local para acender velas, dentro e fora da capela. Coordenadas: UTM7046035/22J0354838/Elevação 516 m. 

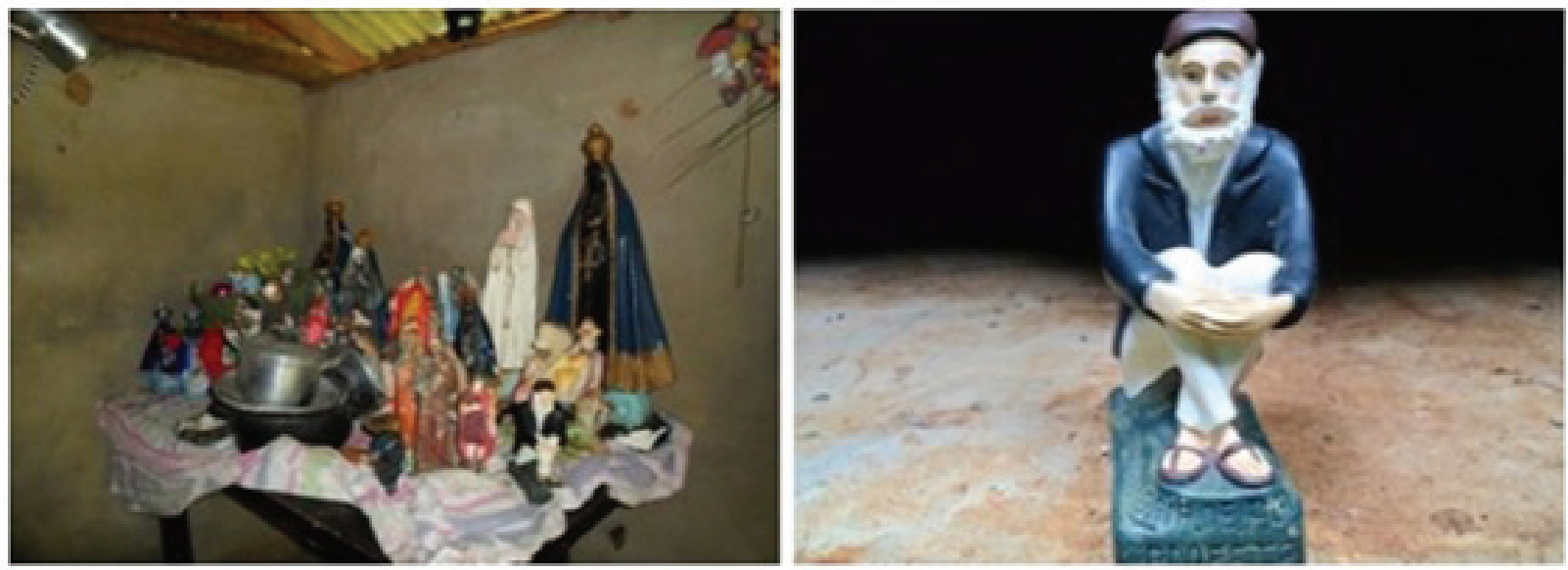

Figura 1: Imagens presentes na capela e fonte d'água na Linha Cerro Doce, localizada dentro da Terra Indígena Xapecó no município de Ipuaçu, Santa Catarina

Fonte: Acervo fotográfico de Tiago João Benetti (2013

\section{Fonte d’Água Ipuaçu}

Fonte d'água localizada no centro da cidade de Ipuaçu/SC, próxima ao silo da empresa Coamo, seguindo 300 metros em meio à mata. A água excedente sai do reservatório e segue seu trecho natural, desembocando em um córrego a 50 metros adiante. É bastante visitada e de fácil acesso; porém, o percurso precisa ser feito a pé na parte final do trecho. Existem vestígios de culto no local (restos de velas). Não há imagens ou capelas no local, apenas o reservatório e a fonte relacionada ao Monge. Coordenadas: UTM7054748/22J0355679/Elevação $511 \mathrm{~m}$
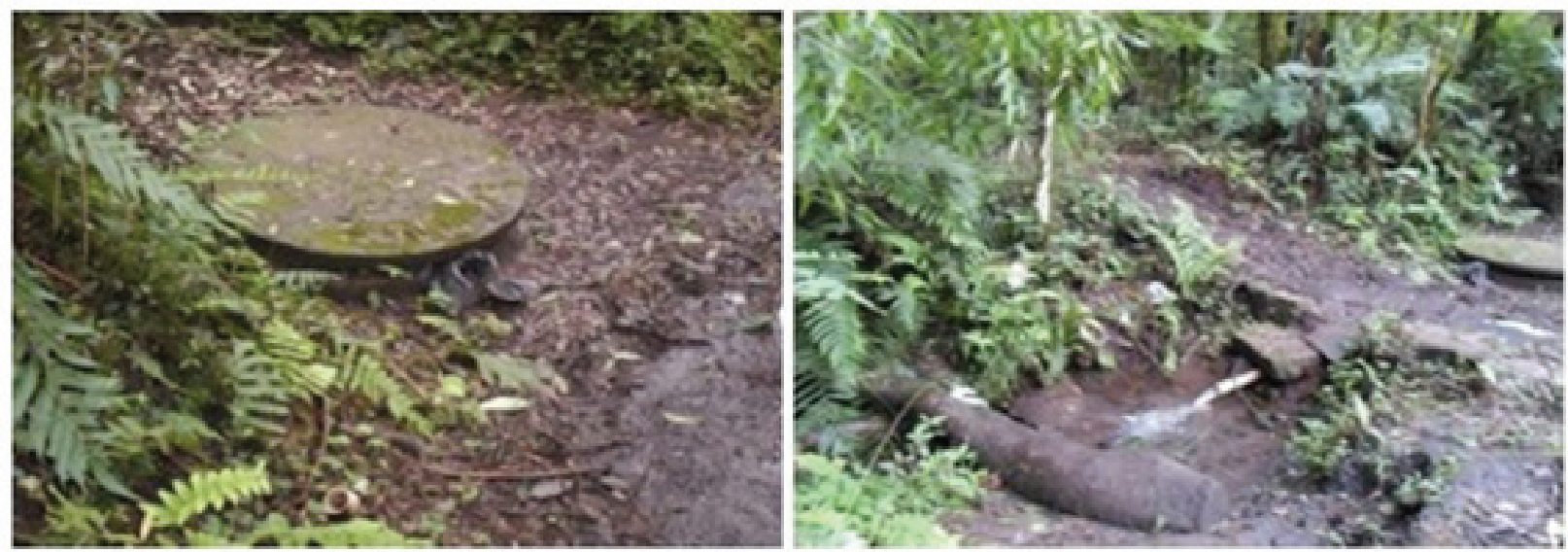

Figura 2: Vista geral da Fonte d'água Ipuaçu, localizada na cidade de Ipuaçu, Santa Catarina Fonte: Acervo fotográfico de Tiago João Benetti (2013).

\section{Fonte d’água Linha Fazenda}

Fonte d'água localizada no interior da cidade de Entre Rios/SC, dentro da Reserva Indígena Xapecó, na localidade denominada de Linha Fazenda, a aproximadamente $12 \mathrm{~km}$ do centro da cidade homônima. No local, afastado e de difícil acesso, além da vertente, existe uma pequena capela em alvenaria, onde observamos várias imagens de santos católicos (Nossa Senhora Aparecida, Nossa Senhora de Fátima, São Jorge). Cabe aqui observar, na Figura 3, a existência de uma imagem que permite inferências sobre a presença de manifestação religiosa que não apenas a católica. 
Observamos, neste sítio, locais de queima de velas, o que evidencia sinais de cultos. Coordenadas: UTM 7039131/22J0350104/Elevação 639 m.
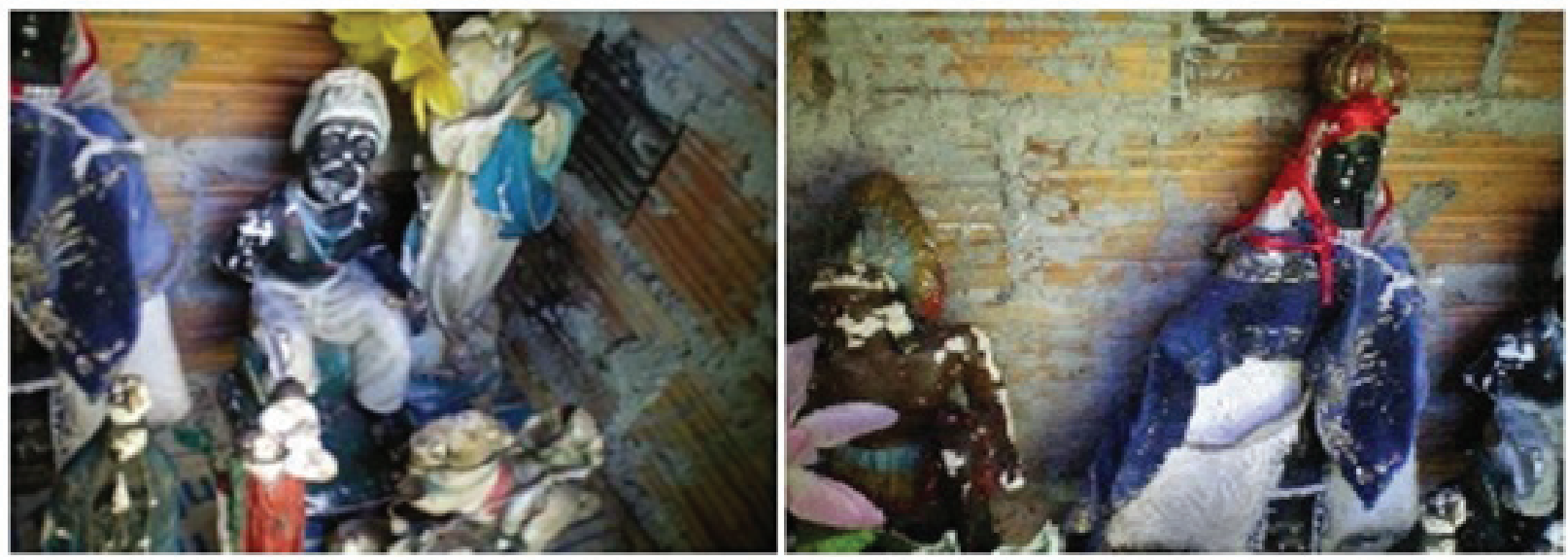

Figura 3: Imagens de divindades de diferentes crenças religiosas depositadas na fonte d'água e capela na Linha Fazenda, cidade de Entre Rios, Santa Catarina

Fonte: Acervo fotográfico de Tiago João Benetti (2013).

A imagem em questão, relativamente simples do ponto de vista iconográfico ${ }^{2}$, retrata um homem negro, de barba branca, pés descalços, sem camisa, vestindo uma calça monocolor, um turbante (ou adorno na cabeça que, aparentemente, sugere um turbante), dois colares em volta do pescoço e um terceiro colar que cruza seu tronco sobre o ombro direito, passando por baixo do braço esquerdo, mesmo braço da mão que segura um cachimbo. O outro braço - direito - recolhe a mão para trás de seu tronco. Sua posição é sentada.

Santos (1999) nos ajuda a interpretar a imagem descrita ao analisar a construção simbólica da figura dos Pretos Velhos ${ }^{3}$, entidades que, de acordo com a autora, são tradicionalmente identificadas com o universo religioso umbandista, não se restringindo, contudo, a esse panteão. Uma visita à literatura sobre as religiões afro-brasileiras nos indica a presença de Pretos Velhos também em outras manifestações religiosas, tais como o Candomblé de Caboclo e Catimbós. A autora apresenta o personagem "Preto Velho" também a partir de uma imagem retratada como a figura de "[...] um negro idoso sentado num toco de árvore em meio a uma rica vegetação, fumando cachimbo, ostentando uma guia em volta do seu dorso nu' ${ }^{4}$ em contraste com sua calça de algodão" (SANTOS, 1999, p. 9). Andrade Júnior (2013, p. 10), igualmente, destaca o cachimbo enquanto elemento característico na representação de Pretos Velhos, bem como a postura pela qual esses personagens são representados: "sentados em seus banquinhos ou troncos de árvores".

A análise da imagem enquanto um objeto concreto, tangível, e os elementos nela presentes, que, de acordo com as referências trazidas ao texto, nos impelem a associá-la ao universo religioso umbandista, endossa a permissão de interpretála como a representação de um Preto Velho. Em sua tese de doutorado onde estudou o processo de constituição da religião Umbanda, em 1908, na cidade do Rio de Janeiro, Costa (2013, p. 139) a afirma como uma religião produto de um processo sincrético originado a partir do século XVII, em "comunidades afrolusobrasileiras, denominadas Calundus". Nesse processo de formação da religião, identificado como sincrético, a autora indica a influência do catolicismo pela empreitada colonizadora portuguesa, como instrumento usado pelos portugueses na tentativa de sobrepor os seus valores morais e religiosos aos indígenas e aos negros. Entretanto, ainda de acordo com Costa (2013, p. 139), em face desta imposição,

[...] os negros tiveram que se valer de alguns mecanismos que se caracterizaram principalmente como 
acomodação e como resistência. O processo de acomodação dos Calundus pode ser identificado nas negociações empreendidas por eles com aqueles que lhes procuram dominar, onde, como resultado dessas práticas, se estabeleceu um trânsito mais flexível entre eles, suas crenças e a capela. Alguns padres, por exemplo, recorriam aos calunduzeiros, depois que se esgotavam as formas tradicionais da medicina, e também pela ausência de médicos nos locais onde se encontravam.

Entendendo esse contexto de relações que envolveram atores de diferentes matrizes religiosas, suas trocas, negociações, interferências e, sobretudo, as características da representação do Preto Velho, é possível pensar um sincretismo religioso materializado no emprego e na disposição das imagens constantes na Figura 3, no cenário em que se localiza a capela. A leitura desse sincretismo, porém, não se reduz à presença e consequente observação da imagem que representa um Preto Velho, pois é possível notar na mesma figura a existência de uma imagem que indica a representação de um personagem indígena.

De acordo com a Figura 3, a imagem representa um homem com o dorso nu, cabelos negros compridos, na altura do ombro, com um cocar de cores azul, amarela e vermelha mesma configuração cromática do que parece ser um saiote de penas. Ao estudar os sentidos e o alcance psicológico da entidade denominada Caboclo, nos rituais de Umbanda, Rotta (2010), em sua dissertação de mestrado, justifica a escolha por essa entidade específica por ser, ao lado dos Pretos Velhos, amplamente conhecida no universo umbandista. A autora contribui para a compreensão da imagem constante na Figura 3, a partir do prisma umbandista, ao afirmar que:

[...] os caboclos são geralmente associados a uma imagem do indígena brasileiro não só nas comunidades umbandistas como nos trabalhos acadêmicos tradicionais sobre o tema. Em rituais onde eles aparecem, podem-se observar acessórios como penas, cocares, tacapes, arcos e flechas. (ROTTA, 2010, p. 35).
A afirmação de Rotta (2010), no que tange à caracterização material da entidade, encontra respaldo na representação imagética pelo uso do cocar. Além disso, a autora sustenta que os caboclos são associados à imagem do indígena brasileiro, associação essa não restrita apenas ao universo litúrgico da religião, mas admitida, também, no terreno das produções acadêmicas.

Um exemplo de produção acadêmica acerca desse elemento do panteão umbandista denominado Caboclo, o estudo de Pires Nogueira (2014) ajuda a entender o processo pelo qual essa entidade se constituiu e se estabeleceu no quadro litúrgico e ritualístico umbandista. Ao avaliar a manifestação religiosa Candomblé de Caboclo, o autor afirma que a influência "Banto", especialmente o culto de espíritos ancestrais vinculados à terra, foi determinante na constituição do Candomblé de Caboclo - que posteriormente influenciou a Umbanda - a partir do culto da ancestralidade vinculada à terra brasileira, isto é, o indígena. É importante destacar que, nesse culto à ancestralidade e diante da pluralidade de populações indígenas, não se priorizou um povo específico.

Expressiva é a produção científica que disserta sobre a entidade umbandista Caboclo associando-a ao indígena ${ }^{6}$ e a maneira como essa entidade perpassa variadas manifestações religiosas de matriz africana, incluindo a Umbanda, esta que, por sua vez, considera também as influências do catolicismo. Essa premissa, uma vez admitida, permite entender a disposição das imagens de um Preto Velho e de um Caboclo ao lado da imagem de uma santa católica. Não é, todavia, o objetivo primeiro deste artigo investigar mais profundamente o sincretismo religioso e a influência de religiões de matrizes africanas e indígenas - o que pode ser feito em outra oportunidade - nos lugares-objetos de levantamento arqueológico considerados neste texto.

\section{Vertente do Monge João Maria}

Fonte d'água localizada no centro da cidade de Xanxerê/SC, próxima ao Estádio do Tabajara Futebol Clube, na Rua Nereu Ramos, esquina com Rua Antônio Vitório Giordani. Essa vertente foi canalizada no início dos anos 1990 e segue junto à captação de água da chuva existente na rua, desembocando no Rio Xanxerê, cerca de 40 metros 
adiante. Essa fonte frequentemente é citada pelos moradores, mas atualmente nenhum vestígio físico dela está perceptível.

Coordenadas: UTM702703573/ 22J0360205/ Elevação 775 m.

\section{Fonte Sguario}

Fonte d'água localizada no interior da cidade de Xanxerê/SC, na Linha Barro Preto, a 100 metros da Rodovia SC-480, Km 346,5, em terras de propriedade da família Sguario. Tratase de uma vertente. Parte dela está canalizada e abastece residências da referida família, enquanto o restante segue um pequeno córrego formando uma área alagadiça (banhado) adiante. Não foram evidenciados vestígios de cultos quando da visita ao local, mas muitas pessoas continuamente buscam dessa água para consumir em suas residências. Coordenadas: UTM 7032191/22J0359402/Elevação: $727 \mathrm{~m}$.

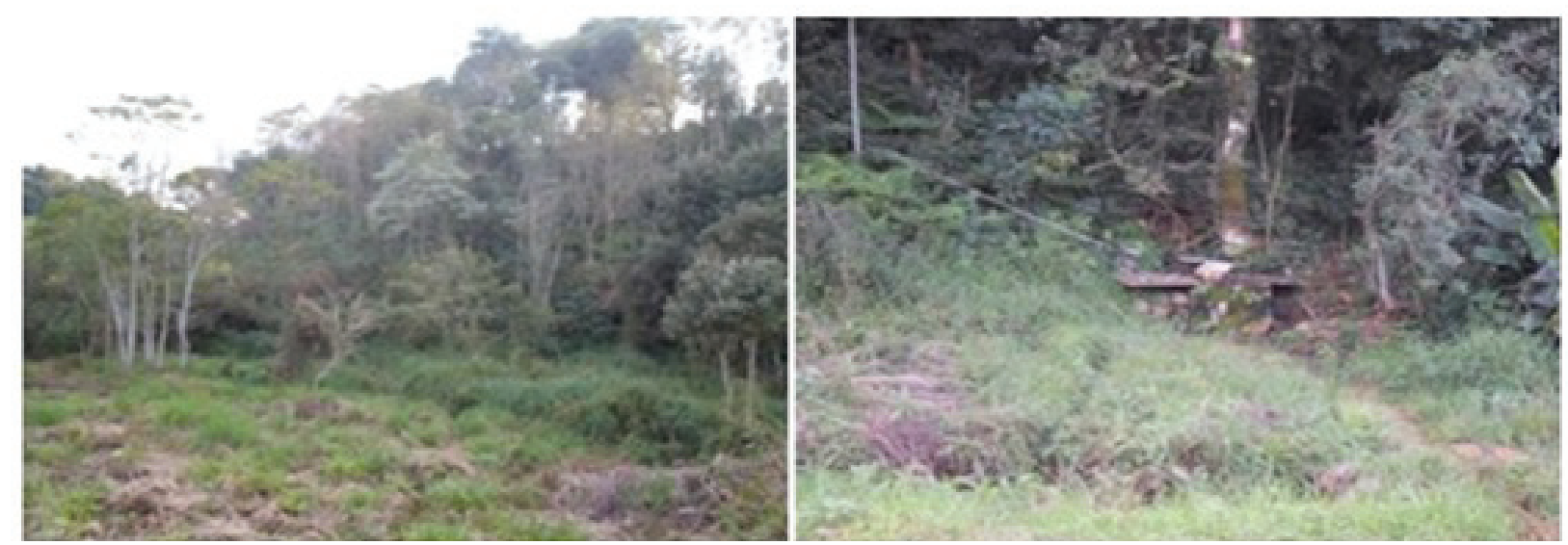

Figura 4: Fonte d'água localizada na Linha Barro Preto, na cidade de Xanxerê/SC Fonte: Acervo fotográfico de Tiago João Benetti (2013).

\section{Fonte d’água Cambrussi}

Fonte d'água localizada no interior da cidade de Bom Jesus/SC, próxima ao silo da Granja Cambrussi, a 250 metros da Rodovia SC-480 - Km 493. Trata-se de uma vertente d'água, com parte dela canalizada, cuja função é abastecer a referida granja. O restante segue em um córrego (sanga) que desemboca no Rio Chapecozinho, 400 metros adiante, próximo à cabeceira da ponte e à Usina Hidrelétrica Passo Velho. Coordenadas: UTM 7039790/22J0360346/Elevação 653 m.
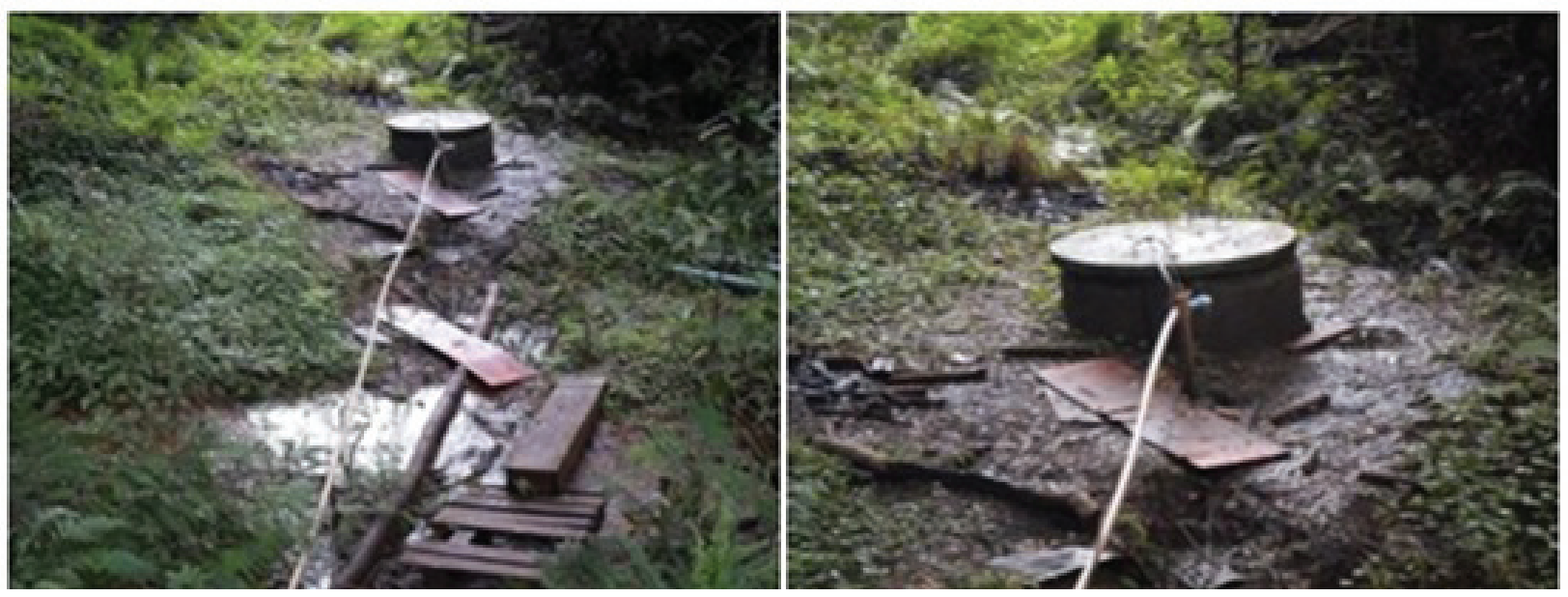

Figura 5: Fonte d’água Cambrussi, localizada na Linha Passo Ferraz, município de Bom Jesus, Santa Catarina Fonte: Acervo fotográfico de Tiago João Benetti (2013). 


\section{Fonte e Capitel Água Santa}

Fonte d'água localizada no interior da cidade de Bom Jesus/SC, próxima à sede da Granja Brasão, na comunidade denominada Água Santa. Atualmente, parte da fonte está canalizada, sendo utilizada nas moradias dos funcionários da granja. $\mathrm{O}$ restante da vertente segue caminho natural e desemboca no Rio Chapecozinho, cerca de 800 metros adiante. No local, também existe uma capela edificada em alvenaria. Contudo e de acordo com informações orais, havia anteriormente no mesmo local uma capela de madeira construída na década de 1960 e que, devido à ação do tempo, foi destruída e substituída pela estrutura atual. Hoje, nessa pequena capela (também conhecida como capitel), existem várias imagens de santos católicos e uma fotografia atribuída ao Monge João Maria. Coordenadas: UTM: 7038733/22J0362758/ Elevação $700 \mathrm{~m}$.
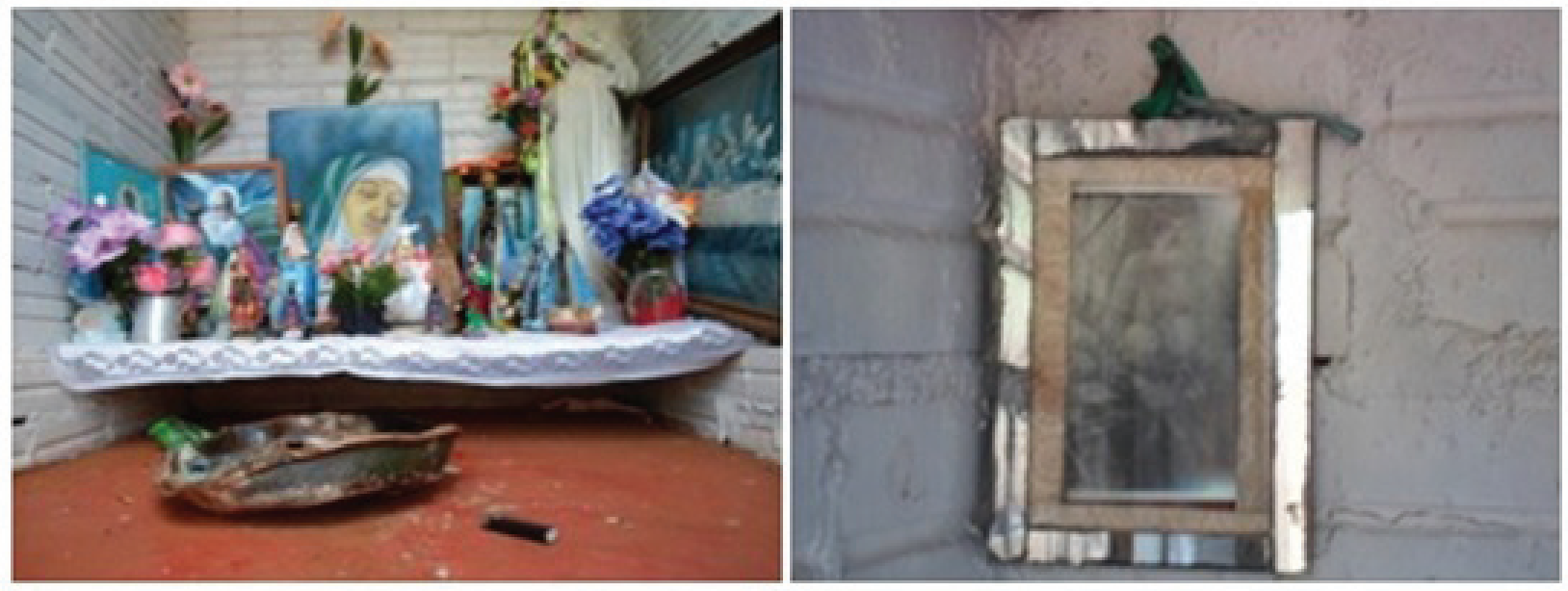

Figura 6: Objetos e imagens presentes no interior da Fonte e Capela Água Santa, município de Bom Jesus, Santa Catarina

Fonte: Acervo fotográfico de Tiago João Benetti (2013).

\section{Religiosidade, paisagens e a exaltação do sagrado}

Ao término do levantamento das fontes d'água relacionadas ao Monge do Contestado na região de Xanxerê, Santa Catarina, foi possível observar, em diversos elementos que compõem o imaginário dos fiéis, a devoção a São João Maria. Itens relacionados aos santos da igreja católica (São Jorge, Nossa Senhora Aparecida, dentre outros), crucifixos e imagens, nos dão uma ideia da forte influência do catolicismo nas comunidades estudadas. As manifestações relacionadas à Igreja Católica e a São João Maria foram encontradas nas três capelas visitadas, mas com algumas divergências em itens complementares, demonstrando as particularidades de cada local.
São João Maria está representado materialmente em duas capelas: uma fotografia na capela da comunidade de Água Santa e uma pequena estátua com os dizeres "profeta" na capela da comunidade de Cerro Doce. Nesta última, além das imagens, existem panelas e formas de armazenamento de alimentos em sinal de oferenda ao Monge, provavelmente significando a solicitação de auxílio espiritual para que não falte alimento nas mesas dos seus fiéis. Também estão presentes outros elementos materiais como enfeites diversos (flores de plástico, papéis de parede), tornando o ambiente, inclusive para aqueles que o visitam, mais "festivo" e familiar.

O sincretismo religioso está presente em alguns dos locais visitados. Destaca-se a capela de Linha Fazenda, onde, juntamente com imagens católicas, registram-se duas imagens singulares e 
que não foram mencionadas em outros dos locais descritos neste artigo: uma imagem representando um Caboclo e outra representando um Preto Velho. A capela está situada dentro da Terra Indígena Xapecó, evidenciando o quão o culto a São João Maria está presente entre as comunidades indígenas, conforme vêm apontando estudos sobre o assunto (BUBA; NOTZOLD, 2016).

Vestígios materiais mostrando a ocorrência recente de rituais de culto no interior desses espaços estão materializados por restos de velas, presentes em quase todos os lugares visitados. Outros traços também mostram que os espaços sagrados têm sido de modo recente e recorrente visitados, por exemplo, os caminhos marcados, que, por conta do pisoteio constante, sinalizam uma via de constante caminhada, sobretudo em áreas mais ermas em que a vegetação de porte variado predomina e, por isso, pode-se visualizar melhor tais marcas.

O conjunto de toda a materialidade observada, das estruturas físicas corporificadas em capelas, fontes d'água e grutas, até os objetos, de fotografias a velas, é objetivado como um símbolo ou código cultural disposto na paisagem da região de Xanxerê, marcando o território com elementos religiosos importantes para determinados grupos coletivos que, do ponto de vista étnico e socioeconômico, estão pulverizados nos mais diferentes segmentos, de indígenas a descendentes de europeus, de pobres a ricos. Conforme Geertz (2000, p. 68), nesse sentido,

Símbolos são atos culturais, construções, como a cruz, ou um pedaço de pedra pintado como "churinga", são elementos simbólicos, formando o conteúdo positivo. Ao contrário dos genes, os padrões culturais são repassados aos indivíduos por meio externo.

Analisando puramente os dados dispostos neste artigo, somente em dois objetos foi possível observar elementos étnicos distintos e marcados, isto é, que representam abertamente a ligação ou afiliação cultural: a estatueta de um Preto Velho e um Caboclo, conforme já descritos. Além disso, existem dois espaços sagrados que estão dentro de uma terra indígena, cujos habitantes são compostos por indígenas Kaingang e Guarani. Já do ponto de vista socioeconômico, não se observou nenhum tipo de marcador de diferenciação, praticamente impossível de se registrar nessas circunstâncias.

Para além do caráter cultural, os espaços registrados se mostram como sítios sagrados, onde ocorre a subliminaridade, isto é, locais que permitem a comunicação com o mundo extrafísico. Esses espaços se apresentam, por seu histórico (conexão temporal com os monges), por seus aspectos formais (nascentes d'água, gruta, capela) e pelos objetos (velas, estatuetas, fotografias) como lócus privilegiado de realizações comunicacionais com entidades espirituais, conforme afirma Eliade (2006, p. 19):

No interior de um recinto sagrado, o mundo profano é transcendido, nos níveis mais arcaicos de cultura, tornando-se possível a comunicação com os deuses, uma porta onde os deuses podem descer a terra e o homem subir aos céus.

A manutenção dessas capelas, fontes e locais de culto demonstram as particularidades de cada comunidade em se integrar ao universo religioso, influenciando o cotidiano dos seguidores nos espaços relacionados a São João Maria. A memória acerca do Monge está fragmentada entre obras a respeito do peregrino e nas lembranças do povo que o cultua, relatando fatos protagonizados pelo profeta. De acordo com Lino (2011, p. 87),

[...] as fontes sagradas mostram como
elementos naturais foram apropriados
pelos grupos humanos que ocuparam
a região do Contestado em tempos
históricos, ressignificados a partir de
uma expectativa do sagrado, reunindo,
num só tempo, elementos religiosos
cristãos e pagãos.

O estudo de Welter (2007) mostra como os preceitos que envolvem a peregrinação dos monges ainda estão presentes na região, havendo, por exemplo, ligações entre as profecias de João Maria com o contexto de vida atual, sobretudo no que concerne ao avanço da técnica no mundo rural, como menciona Welter (2007, p. 172): 
O surgimento de inovações tecnológicas como asfalto, avião, energia elétrica, telefone, internet, equipamentos e produtos agrícolas modernos. João Maria falaria por metáforas, como seria típico dos profetas, e só aos poucos estas inovações foram sendo decifradas pelos joaninos como a "cobra preta' e "os corvos pelos ares", os "gafanhotos de aço" e as "teias de aranha". Embora grandes partes das inovações sejam vistas pelos joaninos como algo positivo, muitos discursos enfatizam o aspecto nefasto destas inovações para o ser humano e as relações sociais como um mal.

A citação supracitada mostra como as representações sobre os monges ainda estão muito presentes nas comunidades da região. Além disso, tais cognições religiosas possuem seus correlativos na paisagem, por meio da criação e manutenção de espaços sagrados materializados em grutas, cruzeiros, fontes d'água e capelas. Desse modo, “[...] lugares sagrados são indubitavelmente os principais pontos de referência que norteiam a construção da memória social dos grupos humanos na paisagem" (LINO, 2011, p. 55).

Assim, a criação e a manutenção de espaços sagrados possibilitam a ligação entre diferentes gerações na mesma crença, independentemente do recorte temporal, aproximando passado e presente em um continuum religioso que conta com uma forte expressão material na paisagem: "Para a região do Contestado, essas conexões entre passado e presente com relação aos sítios sagrados é muito evidente. Muitos lugares ainda são visitados atualmente, e muitas festas e rituais foram elaborados a partir de personagens e episódios do passado" (LINO, 2011, p. 56).

Os lugares sagrados aqui descritos se apresentam, portanto, como elementos capitais para a criação de laços de pertencimento, perpassando diferentes gerações desde que os monges deixaram suas marcas no espaço regional. Esses lugares possuem assim uma função pedagógica, no sentido de que transmitem fortes símbolos religiosos estruturados em formações naturais. Geertz (2000, p. 69) acrescenta que:
[...] o homem precisa de modelos, estímulos, para atingirmos a concepção de como realizar alguma tarefa, simbólicas ou não simbólicas, modelando o indivíduo ao aprendizado, entendimento. A percepção de um conjunto estrutural, processos ou programa, é a essência do pensamento humano, a intransponibilidade, a motivação, serve como uma espécie de ética que mantém a sua sociedade consciente de sua propriedade, pertencimento a um grupo específico.

Os espaços religiosos são, também, espaços culturais. Nos casos descritos, se observa uma inter-relação íntima entre religião e cultura, impregnada nas escolhas de criação de lugares de culto e da bagagem material que os compõem. E, independentemente "[...] dos locais de crenças, os templos seguem tendências culturais, diferindo em diferentes culturas, representando formas e intuitos conforme influência de histórias de seus ídolos" (ELIADE, 2006, p. 35).

A religiosidade é mutável, dinâmica, adaptando-se à realidade de cada grupo em que está inserida, nos seus costumes, nas suas crenças e, principalmente, na maneira como é exercida, fazendo nascerem as diferenças, mesmo quando está inclusa no mesmo sistema endógeno no qual foi criada.

São essas manifestações que compõem o cotidiano de crenças dos fiéis do Monge do Contestado na região de Xanxerê/SC, mostrando que religião e cultura caminham juntas, utilizandose de elementos naturais e culturais para sacralizar a imagem de São João Maria, buscando conforto e auxílio espiritual, alimentando a crença no profeta peregrino e transmitindo - de geração em geração - suas prédicas.

\section{Considerações finais}

Este estudo apresentou o resultado de trabalhos de campo visando ao registro de sítios históricos associados à passagem de monges santos na região oeste de Santa Catarina, especialmente no município de Xanxerê e arredores. Disso resultou o registro de nove espaços sagrados, divididos entre grutas, fontes d'água e capelas. 
Pretendeu-se, desse modo, contribuir com os estudos sobre a religiosidade católica da região, que se reveste de caráter peculiar devido às interseções entre o catolicismo oficial e a influência de monges eremitas que circularam pela região entre os séculos XIX e XX, profetizando, aconselhando, medicando e batizando a população de áreas rurais, carente de assistência espiritual devido à escassez de padres e igrejas (em alguns casos, esse fato ainda se faz presente).

O presente estudo demonstra que as comunidades regionais ainda hoje seguem realizando visitas e rituais nos espaços do monge, que mostram ainda serem potentes recursos para marcar a paisagem de modos físico e simbólico, no que concerne a aspectos do sagrado.

A devoção a santos católicos, e de outras religiões auxiliam para a compreensão do significado que São João Maria estabelece aos seus seguidores, transformando o ermitão em autoridade religiosa, na promessa de melhores condições de vida e contato direto com o criador, firmando alianças entre as partes envolvidas, ultrapassando fronteiras hierárquicas e temporais.

Tais ações buscam a legitimação de uma cultura que se apropria de diversos elementos para formar uma religiosidade regional, afirmando a crença no santo local e aproximando a fé da obtenção das graças. Parafraseando Welter (2007): "O profeta São João Maria continua encantando no meio do povo".

\section{Notas}

1 Sobre o catolicismo popular na região do Contestado, ver os estudos clássicos de Queiroz (1966) e Monteiro (1974).

2 Por iconografia, tomamos aqui o conceito proposto por Panofsky (1991), que consiste em uma análise classificatória e descritiva da imagem. A análise iconográfica não se dedica à reflexão dos elementos constantes em uma imagem.

3 Para saber mais sobre os personagens Pretos Velhos, suas características e atribuições na liturgia e no ritual umbandista, ver Santos (1999).

4 Ao avançar no seu estudo, Santos (1999) atenta para a existência de imagens com diferentes representações de Pretos Velhos. Segundo a autora, a imagem de Preto
Velho, cujo tronco está nu, indica uma especificidade ritualística do personagem representado sem, no entanto, descaracterizá-lo como tal.

5 De acordo com Daibert (2015), os "Bantos" correspondem a um conjunto de povos que habitavam a região central do continente africano em que atualmente se localizam Angola, Gabão e Congo.

6 Para saber mais, ler: PRANDI, Reginaldo; VALLADO, Armando; SOUZA, André Ricardo de. Candomblé de Caboclo em São Paulo. In: PRANDI, Reginaldo (Org.). Encantaria Brasileira. Rio de Janeiro: Pallas, 2001. p. 125.

\section{Referências}

BUBA, Nathan Marcos; NOTZOLD, Ana Lúcia. Os "joaninos" entre os Kaingang da Terra Indígena Xapecó. In: ENCONTRO ESTADUAL DE HISTÓRIA DA ANPUH-SC, 16., 7-10 jun. 2016, Chapecó. Anais eletrônicos [...]. Chapecó: ANPUH, 2016. Disponível em: http://www.encontro2016. sc.anpuh.org/resources/anais/43/1464445245_ ARQUIVO_NathanANPUH2016.pdf. Acesso em: 22 jun. 2019.

CABRAL, Oswaldo R. João Maria - Interpretação da campanha do Contestado. São Paulo: Companhia Editora Nacional, 1960.

COSTA, Hulda Silva Cedro da. Umbanda, uma religião sincrética e brasileira. 2013. 177 f. Tese (Doutorado em Ciências Humanas) - Pontifícia Universidade Católica de Goiás, 2013.

DAIBERT, Robert. A religião dos Bantos: novas leituras sobre o Calundu no Brasil Colonial. Revista Estudos Históricos. Rio de Janeiro, v. 28, n. 55, p. 7-25, jan./jun. 2015.

ELIADE, Mircéa. O sagrado e o profano - a essência das religiões. São Paulo: Companhia das Letras, 2006.

GEERTZ, Clifford. A interpretação das culturas. São Paulo: Companhia das Letras, 2000.

ANDRADE JÚNIOR, Lourival. "Adorei as Almas": Umbanda, Preto-Velho e escravidão. In: SIMPÓSIO NACIONAL DE HISTÓRIA - ANPUH, 27., 22-26 jul. 2013, Natal. Anais 